\title{
Tykktarm- og endetarmkreft - utvikling fra 1956-1995: Status i Telemark og i bydelene i Oslo og ny masseundersøkelse 1999
}

\author{
Inger Stensvold ${ }^{1}$, Tom Grotmol ${ }^{2}$ og Eystein Glattre ${ }^{2}$ \\ ${ }^{1}$ Avdeling for epidemiologi og helseovervåking, Klinikk for forebyggende medisin, Ullevål sykehus \\ ${ }^{2}$ Kreftregisteret \\ Korrespondanse til: Inger Stensvold, Statens helsetilsyn, Postboks 8128 Dep, 0032 Oslo \\ Telefon $22248905 \quad$ Telefax 22248868 e-post inger.stensvold@helsetilsynet.dep.telemax.no
}

\begin{abstract}
SAMMENDRAG
Kreft i tykktarm og endetarm (kolorektal kreft) er den hyppigste kreftform i Norge for begge kjønn samlet. Hyppigheten har vært økende helt siden registreringen startet tidlig på 1950-tallet. Data fra Oslo har i denne statistikken alltid vært presentert samlet som et fylke. I denne artikkelen vises hyppighet av kolorektal kreft fordelt på kjønn og 25 bydeler samt for fire regioner i Oslo. Utviklingen over tid fra 1956 til 1995 er vist for Oslo og Norge.

Den økende hyppighet av både tykktarm- og endetarmkreft gjennom flere tiår ser ut til å avta noe. Dette gjelder særlig for tykktarmkreft for kvinner og endetarmkreft for menn i hele landet. Det er store variasjoner mellom bydelene i Oslo for begge krefttyper og kjønn. Det er ingen signifikant samvariasjon på bydelsnivå mellom menn og kvinner for hver av de to kreftformene. Det er heller ingen samvariasjon mellom sosioøkonomiske faktorer i bydelene og hyppighet av kolorektal kreft.

Sykdommens utvikling fra adenomatøs polypp til adenocarcinom over en lang periode på 10-15 år gjør den velegnet til screening. En planlagt screeningundersøkelse for kolorektal kreft i Telemark og Oslo er nærmere beskrevet. Resultatene av prosjektet forventes å danne grunnlaget for en samlet nasjonal strategi mot kolorektal kreft.
\end{abstract}

\section{Stensvold I, Grotmol T, Glattre E. Colorectal cancer - secular trend from 1956 through 1995: Results from \\ Telemark and Oslo and new screening for colorectal cancer prevention. Nor J Epidemiol 1998; 8 (1): 37-43.}

\section{ENGLISH SUMMARY}

Colorectal cancer is the most common cancer form in Norway for both genders combined. The incidence rate has been increasing ever since the registration started in the early 1950s. Data from Oslo have always been presented as one county in the registry. This paper presents the incidence rates for colorectal cancer split by genders and the 25 areas in Oslo. In addition, the secular trend from 1956 through 1995 is shown for both Oslo and Telemark counties as well as for the whole country. The increasing incidence rates of both colon and rectal carcinomas have apparently levelled off over the last 10 years. This applies particularly to colon carcinoma in women and rectal carcinoma in men for the whole country.

There was a large variation between the 25 areas of Oslo for both cancer forms and between genders. There was no significant correlation between men and women for either of the two cancer forms at the area level in Oslo. Nor was there any correlation between socioeconomic factors in areas of Oslo and the incidence rate of colorectal cancer.

The vast majority of colorectal carcinomas develop from an adenomatous polyp over a period of 10 to 15 years. This long time span makes the disease well suited for screening. A prospective, randomized sigmoidoscopy screening for colorectal cancer prevention in Telemark and Oslo is being planned, and the present data from these counties serve as important background information before the screening is scheduled to start in January 1999.

\section{INNLEDNING}

Hyppigheten av kolorektal kreft har vært økende i Norge helt siden registreringen begynte tidlig på 1950tallet (1). I denne perioden er insidensen fordoblet, og kolorektal kreft er nå den hyppigste kreftformen her i landet med omlag 3000 nye tilfeller årlig. Prognosen for de nærmeste årene viser en fortsatt økning, særlig for endetarmkreft (2).

De aller fleste tilfeller av kolorektal kreft utvikler seg fra adenomatøse polypper. Det er en latenstid på 10-15 år, noe som gjør sykdommen velegnet til screening. En prospektiv studie fra Telemark (Telemark polyp study I, TPS-I) har vist at systematisk 
sigmoidoskopi med polypektomi reduserer antallet av tilfeller av kolorektal kreft blant et tilfeldig utvalg av normalbefolkningen (3). Det er nå under planlegging en større screeningundersøkelse med sigmoidoskopi der hensikten er å undersøke om resultatene fra TPS-I lar seg reprodusere i en større prospektiv undersøkelse av individer i Telemark og Oslo med aldersbetinget risiko for kolorektal kreft. Telemark er valgt pga. den kompetanse man der har på endoskopiscreening, i tillegg til at det er et gjennomsnittsfylke mhp. hyppighet av kolorektal kreft.

Oslo er valgt som eksempel på et byfylke med en insidens av kolorektal kreft som tradisjonelt har ligget omlag $20 \%$ høyere enn landsgjennomsnittet. I Oslohelsa (4) er kun tykktarmkreft beskrevet, og for første gang ble det vist hvordan hyppigheten av denne kreftformen varierer mellom bydelene.

Hensikten med det foreliggende arbeidet var for det første å studere fordelingen av både tykktarm- og endetarmkreft i bydelene i Oslo. For det andre var det ønskelig å studere utviklingen i hyppighet av de to kreftformene i Oslo og Telemark i forhold til hele landet med hensyn til den nært forestående screeningen for kolorektalkreft i disse fylkene.

\section{MATERIALE OG METODER}

Datagrunnlaget er for perioden 1989-93 og er fra Kreftregisteret. Bydelsnummer er lagt til adressene ved at krefttilfellene for det enkelte år er koblet mot Personregisteret pr. 1.1. i det samme året. Dette betyr at det mangler bydelsnummer på personer som har flyttet inn til Oslo i det året deres krefttilfelle er registrert. I det foreliggende materialet mangler 2,3\% bydelsnummer.

Kreftsykdommene som presenteres er tykktarmkreft (ICD-7:153 Colon) og endetarmkreft (ICD-7:154 Rectum og anus). Data for utviklingen over tid er hentet direkte fra Kreftregisterets siste publikasjon "Cancer in Norway 1995" (1). Det presenteres aldersjusterte rater for alle aldre med verdenspopulasjonen som standard. I alle offisielle publikasjoner fra Kreftregisteret benyttes denne standarden etter en konvensjon mellom de nordiske kreftregistre om at all kreftinsidens skal presenteres på denne måten. Den samme metoden er brukt ved beregning av aldersjusterte data på bydelsnivå i perioden 1989-93.

De aldersjusterte insidensratene (Y) for femårs kalenderperioder $(\mathrm{X})$ ble tilpasset en loglineær modell av typen $\log _{10} \mathrm{Y}=\mathrm{a}+\mathrm{bX}$. Insidenskurvene for landet som helhet kunne gi inntrykk av en avflating fra midten av 1980-årene. For å teste om insidensen av kolorektalkreft for de to siste femårsperiodene (1986-95) avviker fra den forventede insidensen basert på de foregående seks perioder, ble det tilpasset en loglineær modell for perioden 1956-85. Deretter ble det beregnet et 95\% prediksjonsintervall (PI) ekstrapolert til nest siste (1986-90) og deretter til siste femårsperiode (1991-95) forutsatt den samme loglineære trend som i perioden
1956-90 og basert på usikkerheten i de seks første femårsperiodene (5). Dersom de observerte ratene for de to siste femårsperiodene falt utenfor $95 \%$ PI, ble det med en signifikanssannsynlighet på $5 \%$ (p-verdi) konkludert med endring $i$ insidens.

\section{RESULTATER}

\section{Utvikling over tid}

Utviklingen av hyppighet for tykktarmkreft fra perioden 1956-60 til 1991-95 er vist for menn og kvinner i Figur 1. For landet som helhet har det vært en dobling av hyppigheten fra slutten av 50 -årene og fram til i dag. I Oslo har utviklingen vært noe gunstigere, spesielt for kvinner. Mens kvinner i Oslo i den tidligste perioden lå $36 \%$ høyere enn kvinner i Norge, ligger de nå på samme nivå. Data for Telemark er ikke vist på grunn av små tall og store svingninger.

Kreft i endetarmen forekommer sjeldnere enn i tykktarm, og menn har en høyere hyppighet enn kvinner (Figur 2). Også for denne kreftformen har det vært en økning i den aktuelle tidsperioden, fra 2 til 2,5 ganger $\mathrm{i}$ alle gruppene. Hyppighet av endetarmkreft er høyere i Oslo enn i hele landet. I de tre siste 5-årsperiodene ligger raten for menn i Oslo ca. $15 \%$ høyere enn i landet og tilsvarende for kvinner ca. 20\% høyere.

Både for Oslo, Telemark og hele landet ble det tilpasset loglineære modeller som beskrevet i metodedelen, og økningen i insidens per 5 årsperiode er vist $\mathrm{i}$ Tabell 1. Økningen i insidens er sterkest for endetarmkreft og varierer mellom 14\% og 29\%, men for begge fylkene og for hele landet er økningen statistisk signifikant for begge krefttyper og kjønn.

Tabell 1. Estimert økning i hyppighet av kreft i prosent per 5 år for perioden 1956-85.

\begin{tabular}{lrrrrr}
\hline & \multicolumn{2}{c}{ Tykktarm } & & \multicolumn{2}{c}{ Endetarm } \\
\cline { 2 - 3 } \cline { 5 - 6 } \cline { 5 - 6 } Oslo & $7 \%$ & $9 \%$ & & $14 \%$ & $18 \%$ \\
\cline { 2 - 3 } Telemark & $15 \%$ & $15 \%$ & & $29 \%$ & $19 \%$ \\
Norge & $15 \%$ & $14 \%$ & & $19 \%$ & $18 \%$ \\
\hline
\end{tabular}

Framskriving av utviklingstrenden fra perioden 195685 til periodene 1986-90 og 1991-95 ga predikerte aldersjusterte insidensrater (P) med tilhørende 95\% prediksjonsintervall som vist $\mathrm{i}$ Tabell 2 . Her er også presentert de observerte ratene, hentet fra "Cancer in Norway 1995" (1).

For tykktarmkreft hos menn er det små forskjeller mellom observerte og predikerte rater i begge fylker og i hele landet, men hos kvinner er de observerte ratene lavere enn de predikerte i begge tidsperioder og endringene er signifikante for hele landet.

For endetarmkreft har det skjedd en avflating av de aldersjusterte ratene i de fleste gruppene, men endringene er signifikante kun for kvinner i Oslo og for menn på landsbasis. 


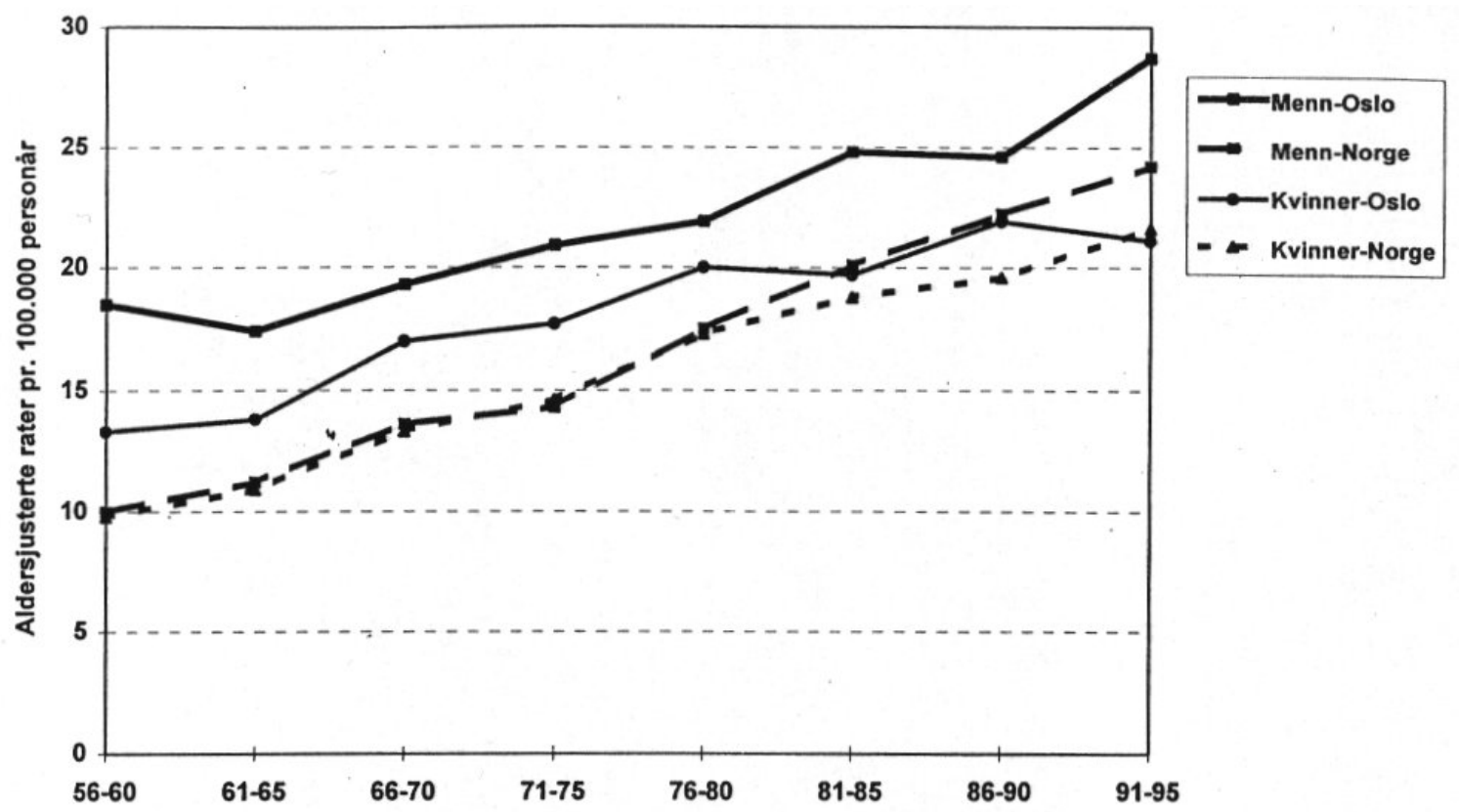

Figur 1. Utviklingen av tykktarmkreft i Oslo og Norge.

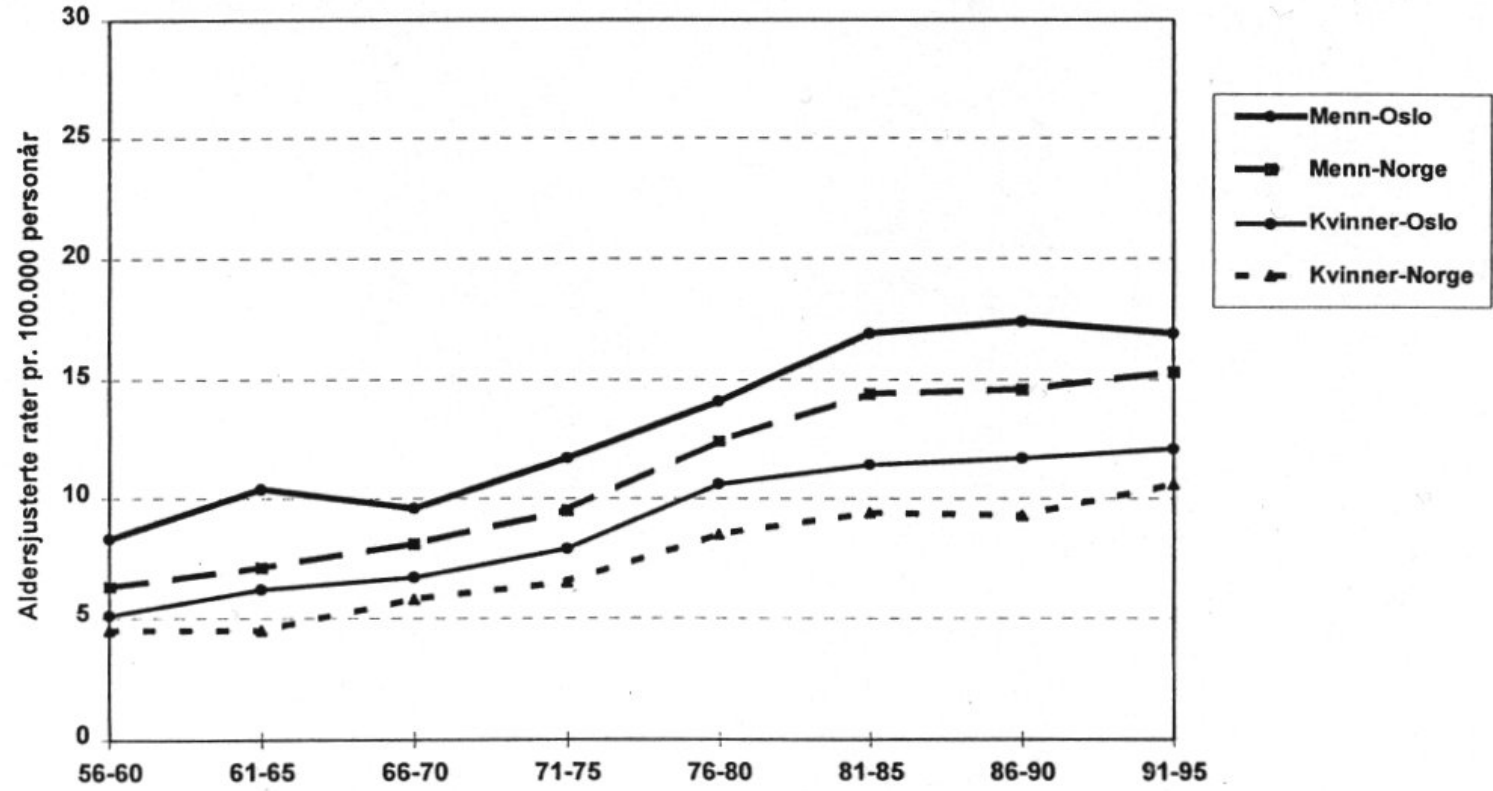

Figur 2. Utviklingen av endetarmkreft i Oslo og Norge.

\section{Fordeling på bydeler}

Det er store variasjoner mellom bydelene, og hyppigheten av kreft i bydelene med de høyeste ratene er 3-4 ganger (statistisk signifikant) høyere enn de i bydelene med laveste rater (Figur 3 og 4). Dette gjelder for begge krefttyper og kjønn.

Det er vanskelig å se spesielle mønstre i fordelingen mellom bydelene i forhold til sosioøkonomisk status etter den inndelingen som er gjengitt i Oslohelsa
(4). For tykktarmkreft er både bydeler med høy (bydel $1,2,21,22,25$ ) og med lav (bydel 6,12) sosioøkonomisk status representert blant bydelene der både menn og kvinner har høy insidensrate. Samvariasjonen på bydelsnivå mellom menn og kvinner er lav $(r=0.25$, $\mathrm{p}=0.2$ ).

Heller ikke for endetarmkreft er det noen tydelige regionale opphopinger, og det er ingen samvariasjon mellom hyppighet av kreft mellom menn og kvinner $(\mathrm{r}=-0.06)$. 
Tabell 2. Observert ${ }^{\S}$ hyppighet av kreft med prediksjonsverdi og -intervall ${ }^{\dagger}$ ekstrapolert til nest siste (1986-90) og siste 5-års periode (1991-95).

\begin{tabular}{|c|c|c|c|c|c|c|c|}
\hline \multirow[b]{2}{*}{ Sted } & \multirow[b]{2}{*}{ Periode } & \multicolumn{3}{|c|}{ Menn } & \multicolumn{3}{|c|}{ Kvinner } \\
\hline & & $\mathrm{O}^{\S}$ & $\mathrm{P}^{\dagger}$ & $\begin{array}{c}\text { Prediksjons- } \\
\text { intervall }^{\dagger}\end{array}$ & $\mathrm{O}^{\S}$ & $\mathrm{P}^{\dagger}$ & $\begin{array}{c}\text { Prediksjons- } \\
\text { intervall }^{\dagger}\end{array}$ \\
\hline & & \multicolumn{6}{|c|}{ Tykktarmkreft } \\
\hline Oslo & $\begin{array}{l}1986-90 \\
1991-95\end{array}$ & $\begin{array}{l}24,6 \\
28,7\end{array}$ & $\begin{array}{l}25,5 \\
27,3\end{array}$ & $\begin{array}{l}(21,0-31,0) \\
(22,2-33,4)\end{array}$ & $\begin{array}{l}21,9 \\
21,1\end{array}$ & $\begin{array}{l}22,9 \\
25,0\end{array}$ & $\begin{array}{l}(18,4-28,4) \\
(19,9-31,5)\end{array}$ \\
\hline Telemark & $\begin{array}{l}1986-90 \\
1991-95\end{array}$ & $\begin{array}{l}21,2 \\
24,5\end{array}$ & $\begin{array}{l}20,7 \\
23,9\end{array}$ & $\begin{array}{l}(13,6-31,4) \\
(15,3-37,1)\end{array}$ & $\begin{array}{l}19,8 \\
18,9\end{array}$ & $\begin{array}{l}20,6 \\
23,6\end{array}$ & $\begin{array}{l}(15,4-27,4) \\
(17,5-32,0)\end{array}$ \\
\hline Norge & $\begin{array}{l}1986-90 \\
1991-95\end{array}$ & $\begin{array}{l}22,2 \\
24,2\end{array}$ & $\begin{array}{l}22,8 \\
26,2\end{array}$ & $\begin{array}{l}(19,9-26,1) \\
(22,7-30,2)\end{array}$ & $\begin{array}{l}19,6^{*} \\
21,6^{*}\end{array}$ & $\begin{array}{l}22,1 \\
25,2\end{array}$ & $\begin{array}{l}(19,9-24,5) \\
(22,6-28,2)\end{array}$ \\
\hline & & \multicolumn{6}{|c|}{ Endetarmkreft } \\
\hline Oslo & $\begin{array}{l}1986-90 \\
1991-95\end{array}$ & $\begin{array}{l}17,4 \\
16,9\end{array}$ & $\begin{array}{l}18,2 \\
20,8\end{array}$ & $\begin{array}{l}(13,4-24,9) \\
(15,0-28,9)\end{array}$ & $\begin{array}{c}11,7 \\
12,1 *\end{array}$ & $\begin{array}{l}13,8 \\
16,3\end{array}$ & $\begin{array}{l}(11,1-17,1) \\
(13,0-20,5)\end{array}$ \\
\hline Telemark & $\begin{array}{l}1986-90 \\
1991-95\end{array}$ & $\begin{array}{l}14,1 \\
13,8\end{array}$ & $\begin{array}{l}20,5 \\
26,5\end{array}$ & $\begin{array}{l}(7,1-59,0) \\
(8,7-80,7)\end{array}$ & $\begin{array}{l}7,6 \\
9,0\end{array}$ & $\begin{array}{r}9,6 \\
11,4\end{array}$ & $\begin{array}{l}(3,4-27,4) \\
(3,8-34,5)\end{array}$ \\
\hline Norge & $\begin{array}{l}1986-90 \\
1991-95\end{array}$ & $\begin{array}{c}14,6 \\
15,3^{*}\end{array}$ & $\begin{array}{l}16,7 \\
19,8\end{array}$ & $\begin{array}{l}(13,9-20,2) \\
(16,3-24,1)\end{array}$ & $\begin{array}{c}9,3 \\
10,6\end{array}$ & $\begin{array}{l}11,1 \\
13,1\end{array}$ & $\begin{array}{r}(8,6-14,3) \\
(10,0-17,1)\end{array}$ \\
\hline
\end{tabular}

$\S$ Observert rate i den aktuelle 5-års perioden (aldersjustert per 100.000 personår).

$\dagger$ Beregnet prediksjonsverdi og -intervall (95\%), ekstrapolert til to 5-års perioder, forutsatt den samme loglineære trenden som i perioden 1956-85 med utgangspunkt i estimatene fra tabell 1.

* Den observerte raten ligger utenfor $95 \%$ prediksjonsintervall.

\section{Aldersspesifikke rater i 4 regioner}

Inndeling av Oslo i 4 regioner er beskrevet i Oslohelsa (4) og i artikkel om dødelighet i dette nummer (6). Fordeling av de to krefttypene i ulike aldersgrupper og fire regioner er vist i Tabell 3. Ratene øker sterkt med økende alder i de fleste undergruppene, men i regionene indre vest og indre øst er ratene hos kvinner for endetarmkreft i aldersgruppene 60-69 år og 70-79 år tilnærmet like. Dette gjelder tilsvarende for tykktarmkreft $\mathrm{i}$ indre vest. De aldersjusterte ratene (50 år og eldre) er ikke signifikant forskjellige mellom regionene for noen av kreftformene.

\section{DISKUSJON}

Når det gjelder rapportering av hyppighet og dødelighet av kreft, er Oslo tidligere behandlet som et fylke. Det nye med denne undersøkelsen og det som er presentert om kreft i Oslohelsa, er at informasjonen er brutt ned på bydelsnivå. Det er i flere sammenhenger tidligere påvist total overdødelighet for bydelene med lavest sosioøkonomisk status (indre øst) i forhold til høystatusområdene på vestkanten $(4,7,8)$, men det er ikke undersøkt tidligere hvordan hyppigheten av ulike kreftsykdommer i Oslo er relatert til sosioøkonomiske forhold.
Våre data viser at det er forskjellige insidensrater av kolorektal kreft mellom de ulike bydelene, men det var ikke noe entydig mønster i fordelingen i forhold til sosioøkonomisk status i bydelene. Noen studier har vist at høy sosioøkonomisk status er positivt assosiert med risiko for tykktarmkreft (9), men det er noe motstridende resultater i litteraturen (10). Sosioøkonomisk status er en variabel som ofte er et indirekte mål for andre og mer direkte risikofaktorer. Når det gjelder kolorektal kreft kan man tenke seg at forskjeller i risikofaktorer som f.eks. kosthold og fysisk aktivitet ligger bak en eventuell assosiasjon mellom krefthyppighet og sosioøkonomisk status.

Den manglende samvariasjonen mellom kjønnene på bydelsnivå blir av oss satt i sammenheng med at krefttilfellene er få når de fordeles på bydeler. Dette er dessuten en korrelasjonsstudie der det ikke har vært mulig å justere for viktige konfunderingsfaktorer som botid i bydelen, flyttemønster og skiftende sivilstatus.

Høy sosioøkonomisk status er en risikofaktor også for prostatakreft og brystkreft $(11,12)$. De to sistnevnte kreftformene viser heller ingen signifikant overhyppighet i bydeler i Oslo med høy sosioøkonomisk status, selv om det er en tendens til høyere insidens i de vestlige deler av byen (4). Dette bekrefter at det er vanskelig å konkludere med noen sammenheng mellom sosioøkonomisk status og insidens av disse kreftformene i en økologisk studie slik som denne. Sam- 
Figur 3. Hyppighet av tykktarmkreft i perioden 1989-93, alle aldre

MENN

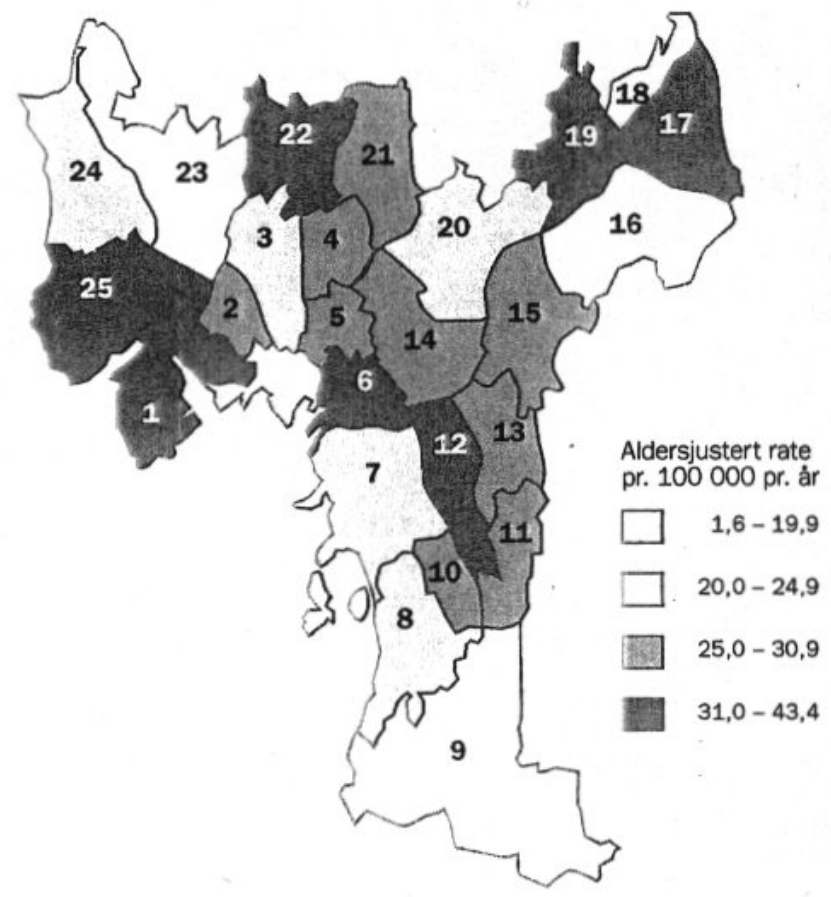

KVINNER

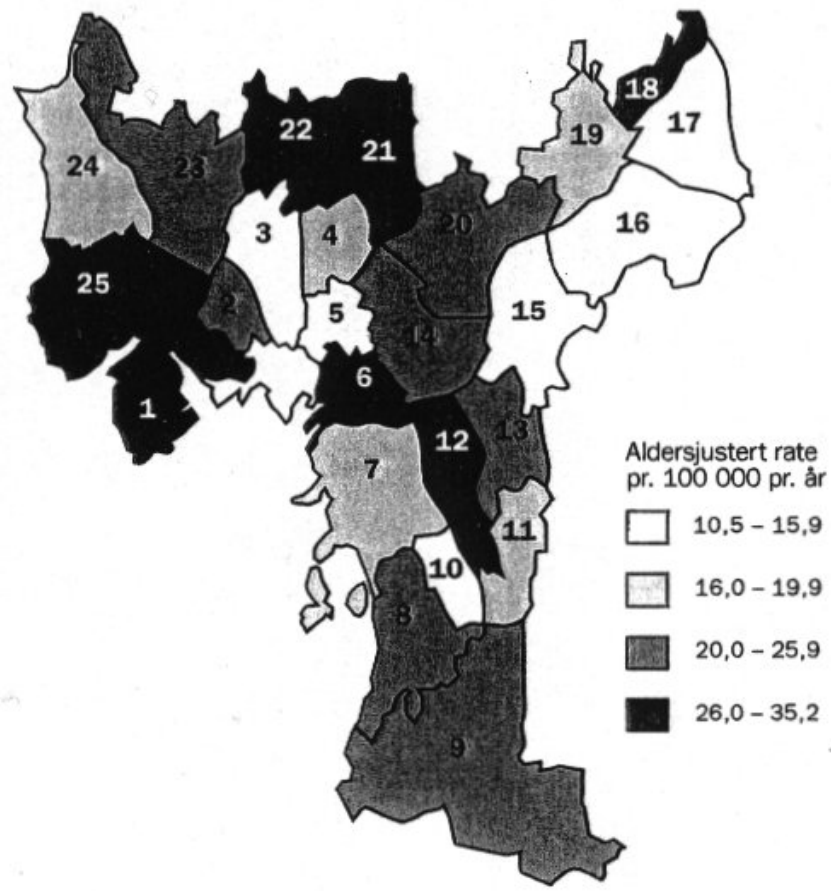

Figur 4. Hyppighet av endetarmkreft i perioden 1989-93, alle aldre

MENN

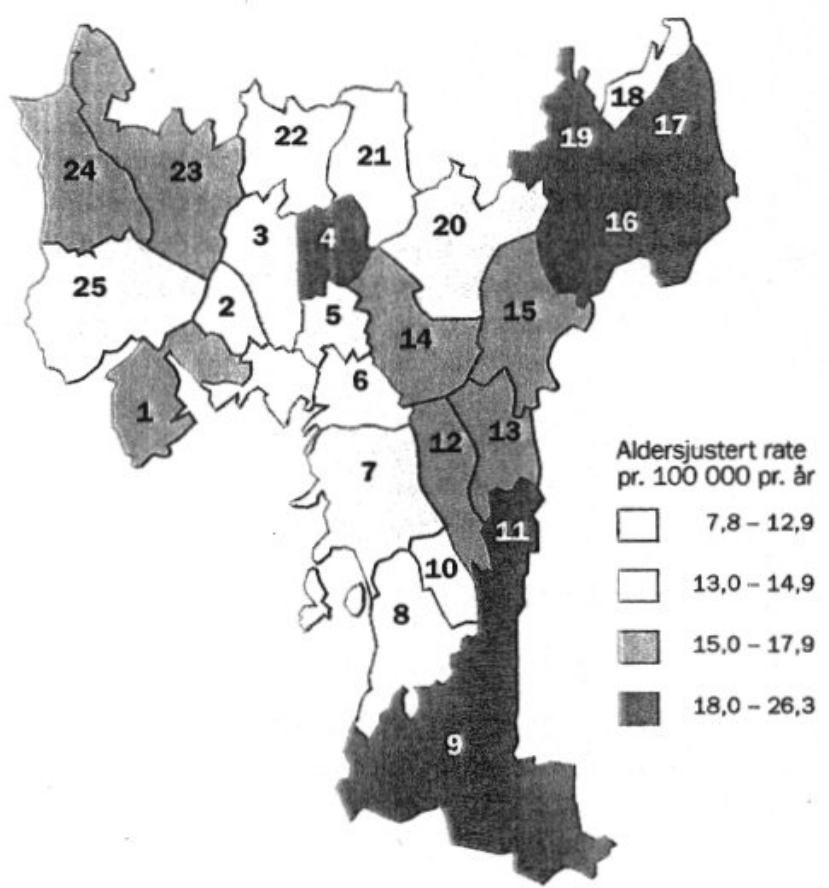

KVINNER

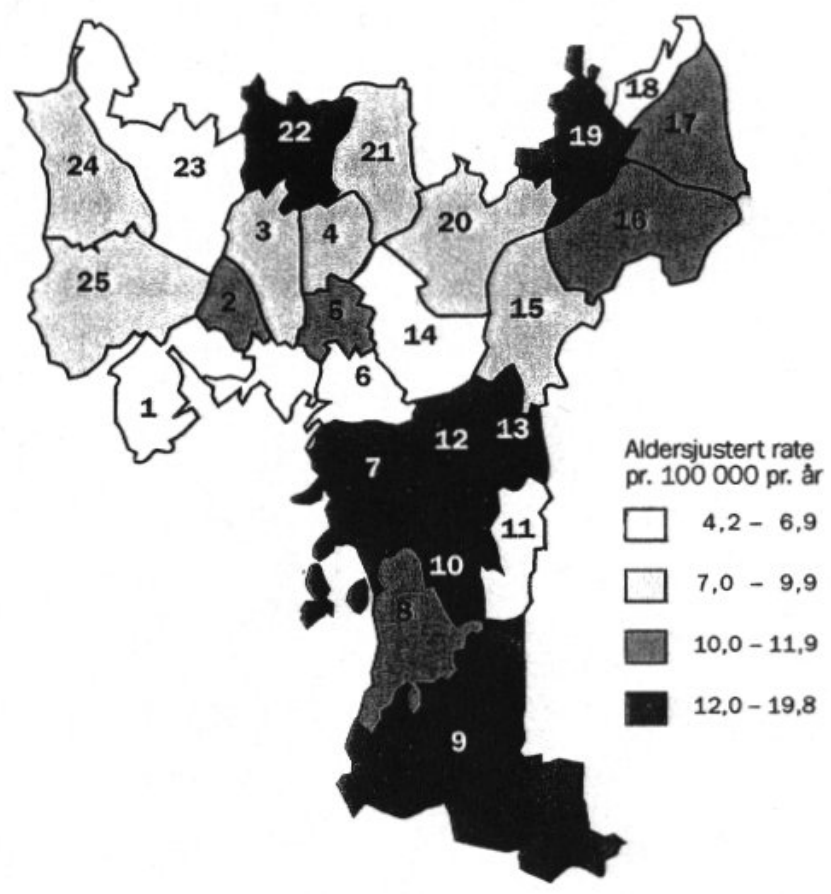


Tabell 3. Hyppighet av kreft i tykktarm og i endetarm i fire regioner i Oslo, 1989-93.

\begin{tabular}{|c|c|c|c|c|c|c|c|c|}
\hline \multirow[b]{2}{*}{ Alder } & \multicolumn{2}{|c|}{ Ytre vest } & \multicolumn{2}{|c|}{ Indre vest } & \multicolumn{2}{|c|}{ Indre øst } & \multicolumn{2}{|c|}{ Ytre øst } \\
\hline & Antall & Rate* & Antall & Rate* & Antall & Rate* & Antall & Rate* \\
\hline \multicolumn{9}{|c|}{ Kreft i tykktarm - menn } \\
\hline $50-59$ & 13 & 49 & 9 & 68 & 6 & 49 & 11 & 25 \\
\hline $60-69$ & 39 & 139 & 11 & 92 & 22 & 182 & 67 & 137 \\
\hline $70-79$ & 65 & 290 & 32 & 296 & 31 & 278 & 80 & 252 \\
\hline $80+$ & 21 & 241 & 23 & 367 & 25 & 440 & 42 & 477 \\
\hline SUM & 138 & 158 & 75 & 161 & 84 & 188 & 200 & 163 \\
\hline \multicolumn{9}{|c|}{ Kreft i tykktarm - kvinner } \\
\hline $50-59$ & 12 & 41 & 11 & 78 & 3 & 30 & 15 & 30 \\
\hline $60-69$ & 35 & 101 & 22 & 129 & 16 & 113 & 46 & 76 \\
\hline $70-79$ & 61 & 188 & 32 & 136 & 50 & 219 & 95 & 190 \\
\hline $80+$ & 65 & 325 & 62 & 293 & 45 & 247 & 67 & 270 \\
\hline$S U M$ & 173 & 157 & 127 & 152 & 114 & 152 & 223 & 138 \\
\hline \multicolumn{9}{|c|}{ Kreft i endetarm - menn } \\
\hline $50-59$ & 7 & 26 & 3 & 23 & 0 & 0 & 12 & 28 \\
\hline $60-69$ & 20 & 71 & 6 & 50 & 13 & 107 & 44 & 90 \\
\hline $70-79$ & 31 & 138 & 15 & 139 & 20 & 179 & 54 & 170 \\
\hline $80+$ & 15 & 172 & 13 & 208 & 16 & 282 & 19 & 216 \\
\hline$S U M$ & 73 & 83 & 37 & 79 & 49 & 108 & 129 & 102 \\
\hline \multicolumn{9}{|c|}{ Kreft i endetarm - kvinner } \\
\hline $50-59$ & 7 & 24 & 2 & 14 & 2 & 20 & 9 & 18 \\
\hline $60-69$ & 19 & 55 & 9 & 53 & 7 & 50 & 30 & 50 \\
\hline $70-79$ & 25 & 77 & 14 & 60 & 13 & 57 & 57 & 114 \\
\hline $80+$ & 25 & 125 & 23 & 109 & 23 & 126 & 23 & 93 \\
\hline$S U M$ & 76 & 68 & 48 & 57 & 45 & 60 & 119 & 70 \\
\hline
\end{tabular}

* Aldersspesifikke rater pr. 100.000 personår, for sum er raten aldersjustert med Oslos befolkning som standard.

menlikningene skjer på gruppenivå (her bydelene), og man har ikke informasjon om enkeltindividenes sosioøkonomiske status eller livsstil for de som får kreft og de som ikke får kreft. En annen grunn er det lave antall observerte krefttilfeller i de 25 bydelene for alle disse kreftformene.

Det viktigste funnet i denne undersøkelsen er at den økende insidensen av både tykktarm- og endetarmkreft gjennom flere tiår ser ut til å avta noe. Dette gjelder særlig kvinner på landsbasis der insidensraten for tykktarmkreft har flatet noe av i løpet av de to siste femårsperiodene (1986-1995) sammenliknet med de seks foregående femårsperiodene (1956-90). For menn, derimot, ser det ikke ut til å ha skjedd noen endring i løpet av de to siste femårsperiodene. De tilsvarende tallene for Oslo og Telemark er for små til at man kan påstå at insidensratene har endret seg.

For endetarmkreft har det trolig også skjedd en avflating av de aldersjusterte insidensratene både for kvinner og menn i løpet av den siste femårsperioden. Selv om denne endringen er signifikant bare for kvinner i Oslo og for menn på landsbasis, ligger de observerte ratene betydelig lavere enn de predikerte verdiene også for menn i Oslo og kvinner på landsbasis og for begge kjønn i Telemark.

Selv om den langvarige økningen av hyppigheten av kolorektal kreft ser ut til å ha avtatt noe i løpet av de siste årene, er det fortsatt den hyppigste kreftformen her i landet for begge kjønn samlet. Sykdommens utvikling fra adenomatøs polypp til adenocarcinom over en lang periode på 10-15 år gjør den velegnet til screening. Dette har vært bakgrunnen for at norsk gastrointestinal cancergruppe (NGICG) tok initiativ til at det i 1997 ble nedsatt en arbeidsgruppe som skulle planlegge en større prospektiv, kontrollert og randomisert screeningundersøkelse med endoskopi for å redusere dødelighet og hyppighet av kolorektal kreft. Prosjektet er også i tråd med anbefalingene fra Norsk kreftplan (13) som foreslo at «forskning/utprøvning bør starte i en region eller område med både kvalitativ og kvantitativ kompetanse innen skopi» og «kartlegging av hvilke ressurser som skal til for å starte screening $\mathrm{i}$ to eller tre prøvefylker». Prosjektet er finansiert av Den Norske Kreftforening og Sosial- og helsedepartementet, og oppstart er planlagt i januar 1999. Nylig (juni 1998) har også Stortingets helse- og 
sosialkomite gitt sin tilslutning til at det startes en screeningundersøkelse for kolorektal kreft. Resultatene av prosjektet forventes å danne grunnlaget for en samlet nasjonal strategi mot kolorektal kreft.

I den planlagte screeningundersøkelsen for kolorektal kreft vil kvinner og menn bosatt i Oslo og Telemark i alder 55-64 år bli randomisert til screeninggruppe og kontrollgruppe. En undergruppe av de screenede vil bli tilbudt sigmoidoskopi i kombinasjon med undersøkelse på okkult blod i avføringen for å undersøke om dette gir noen tilleggsgevinst i forhold til sigmoidoskopi alene. Til sammen skal 14000 personer tilbys screeningundersøkelse. Inklusjon pågår over 2 år, og personene vil deretter bli fulgt i 15 år. Den viktigste målsettingen i denne undersøkelsen er å redusere dødelighet og hyppighet av kolorektal kreft ved tidlig diagnostikk og fjerning av mulige forstadier (adenomatøse polypper). De ferske resultatene som er lagt fram her fra begge fylkene gir nyttig bakgrunnskunnskap før screeningen starter.

\section{REFERANSER}

1. Cancer in Norway 1995, Oslo: Kreftregisteret, 1998.

2. Engeland A, Haldorsen T, Tretli S, Hakulinen T, Hörte LG, Luostarinen T, et al. Prediction of cancer incidence in the Nordic countries up to the years 2000 and 2010. APMIS 1993; 101 (Suppl 38).

3. Hoff G, Sauar J, Vatn MH, Larsen S, Langmark F, Moen IE, et al. Polypectomy of adenomas in the prevention of colorectal cancer: 10 years' follow-up of the Telemark Polyp Study. I. A prospective, controlled population study. Scand J Gastroenterol 1996; 31 (10): 1006-10.

4. Rognerud M, Stensvold I (red.). Oslohelsa. Utredningen om helse, miljø og sosial ulikhet $i$ bydelene. Oslo: Oslo kommune - Ullevål sykehus, 1998.

5. Wonnacott TH, Wonnacott RJ. Regression: A Second Course in Statistics. New York: John Wiley, 1981.

6. Stensvold I, Rognerud M, Thelle DS. Dødelighet av alle årsaker i regioner og bydeler i Oslo: Sammenlikning med utvalgte europeiske land. Norsk Epidemiologi 1998; 8 (1): xx-yy.

7. Gjestland T, Moen E. «East is east, and west is west...» En sammenliknende undersøkelse i Oslo øst og Oslo vest i periodene 1890-1940 og 1971-1980. Oslo: Norsk institutt for by- og regionforskning, NIBR rapport 1988:21.

8. Nasjonalatlas for Norge: Helse. Del I: Helsetilstand. Hønefoss: Statens kartverk, 1996.

9. Schottenfeld D. Epidemiology. In: Cohen AM, Winawer SJ, Friedman MA, Gunderson LL (eds.) Cancer of the Colon, Rectum, and Anus. New York: McGraw-Hill, 1995, 11-24.

10. Van Loon AJ, van den Brandt PA, Golbohm RA. Socioeconomic status and colon cancer incidence: a prospective cohort study. Br J Cancer 1995; 71 (4): 882-7.

11. Harvei S, Kravdal Ø. The importance of marital and socioeconomic status in incidence and survival of prostate cancer. Prev Med 1997; 26: 623-32.

12. Stoll BA (ed.) Reducing breast cancer risk in women. Kluwer Academic Publishers, 1995, 41-45.

13. Omsorg og kunnskap! Norsk kreftplan. Oslo: Sosial- og helsedepartementet, NOU 1997:20. 